\title{
EVALUATION OF POTENTIAL HYBRIDIZATION BETWEEN NATIVE FISHES AND THE INVASIVE BLEAK, ALBURNUS ALBURNUS (ACTINOPTERYGII: CYPRINIFORMES: CYPRINIDAE)
}

\author{
Carla SOUSA-SANTOS ${ }^{{ }^{*} \text {, }}$ Paula MATONO², Janine DA SILVA ${ }^{3}$, and Maria ILHÉU ${ }^{2,3}$ \\ ${ }^{1}$ MARE-Marine and Environmental Sciences Centre, ISPA-Instituto Universitário, Lisboa, Portugal \\ ${ }^{2}$ Instituto de Ciências Agrárias e Ambientais Mediterrânicas (ICAAM), Universidade de Évora, Portugal \\ ${ }^{3}$ Departamento de Paisagem, Ambiente e Ordenamento, Escola de Ciências e Tecnologia, Universidade de Évora, \\ Évora, Portugal
}

Sousa-Santos C., Matono P., da Silva J., Ilhéu M. 2018. Evaluation of potential hybridization between native fishes and the invasive bleak, Alburnus alburnus (Actinopterygii: Cypriniformes: Cyprinidae). Acta Ichthyol. Piscat. 48 (2): 109-122.

\begin{abstract}
Background. Freshwater fishes are among the most threatened taxa worldwide. The proliferation of introduced species in the Iberian Peninsula is currently one of the main drivers of native fish declines. One of such species, the bleak, Alburnus alburnus (Linnaeus, 1758), has become widespread in the last 25 years and, due to its phylogenetic proximity, poses a high risk of hybridization with native species. The aim of this study was to improve the current knowledge on this issue by 1) evaluating the presence of hybrids with Alburnus alburnus in the wild, using molecular screening of individuals representing the intermediate morphology and 2) testing if artificial crosses between Alburnus alburnus and the highly threatened native cyprinid Anaecypris hispanica (Steindachner, 1866) resulted in viable hybrid offspring.

Material and methods. The genetic profile of Alburnus alburnus was established using the cytochrome $b$ and beta-actin genes to allow comparisons with the profiles of the sympatric species with which it could potentially hybridize: Anaecypris hispanica; Squalius alburnoides (Steindachner, 1866); and Squalius pyrenaicus (Günther, 1868). This profile was further used to assess if fish with the intermediate morphological features were indeed hybrids. Finally, artificial crosses between Alburnus alburnus and Anaecypris hispanica were conducted to test the viability of the offspring.

Results. Alburnus alburnus individuals were genetically identical to the stocks introduced in Spain and the Czech Republic. A reference library composed of 15 species-specific nDNA loci was built and used to characterize wild fish showing intermediate morphological features. Results showed that Alburnus alburnus is currently hybridizing with males and females of Squalius alburnoides and that morphometric identification is insufficient for a reliable detection of the hybrids. Artificial crosses between the bleak and the highly threatened Anaecypris hispanica did not result in viable offspring.

Conclusion. Phylogenetic relatedness, traduced in the absence of pre- and post-zygotic barriers to reproduction, together with other factors related to the ecology and life history of the species involved are essential for hybridization to occur. As such, the proliferation of the bleak through the Iberian hydrographical network represents a serious additional threat for the already imperilled native Squalius and Anaecypris species.
\end{abstract}

Keywords: hybridization risk, invasive fish species, biodiversity loss, conservation

\section{INTRODUCTION}

Freshwater fish species are recognizably among the most threatened taxa worldwide, facing an increasingly risk of local, regional, or global extinction mostly due to habitat loss and degradation, invasive species proliferation, pollution, over-exploitation, and direct and indirect effects of climate change (Jenkins 2003, Xenopoulos et al. 2005,
Arthington et al. 2016). In the Mediterranean Basin, one of the main hotspots for freshwater biodiversity at a global scale, holding over 200 Key Biodiversity Areas (MáizTomé et al. 2017), the main drivers of native fish declines are water extraction, pollution, and invasive species proliferation (Clavero et al. 2010, Hermoso and Clavero 2011, Hermoso et al. 2012, Gozlan 2012). The Iberian

" Correspondence: Dr. Carla Sousa-Santos, ISPA - Instituto Universitário, Rua Jardim do Tabaco 34, 1149-041 Lisboa, Portugal, phone: +351 218811700, fax: +351 218860954, e-mail: (CSS) carla.santos@ispa.pt, (PM) pmatono@uevora.pt, (JDS) janinepdasilva@gmail.com, (MI) milheu@uevora.pt. 
Peninsula is not an exception to this scenario, with about $68 \%$ of its native cyprinid ichthyofauna imperilled due to similar threats (Sousa-Santos et al. 2016). In particular, the spread and establishment of introduced species poses a strong threat to the conservation of native fishes in highly fluctuating environments and with human-induced disturbances such as the temporary streams of southern Iberia (Hermoso et al. 2012, Ilhéu et al. 2014).

The spread of non-native fish species results in increasing competition (both for food and space) and predation of eggs, juveniles, and adults of the sympatric species, resulting in the disruption of the native community balance, and in a risk of hybridization and genetic introgression (Ribeiro and Leunda 2012, Bangs et al. 2018). Introduced species may also represent an input of new pathogens and parasites to which native species may be vulnerable (Ribeiro and Leunda 2012).

The common bleak, Alburnus alburnus (Linnaeus, 1758), is a small sized cyprinid from central Europe and western Asia which was repeatedly introduced in the Iberian Peninsula in the last 25 years by anglers as a forage species and quickly spread throughout almost all major Iberian water basins (reviewed by Vinyoles et al. 2007). The Iberian populations of this non-native species generally show high effective sizes due to their successful reproduction and recruitment (Carbonero Ciria et al. 2006, Vinyoles et al. 2007, Almeida et al. 2014), with obvious impact on native fish communities. The problem is aggravated by the fact that this species is known to hybridize with other cyprinids (Błachuta and Witkowski 1983/1984, Crivelli and Dupont 1987, Witkowski et al. 2015), especially with Squalius species (Wheeler 1978, Witkowski and Błachuta 1980, Kammerad and Wüstemann 1989, Almodóvar et al. 2012). The potential risk of hybridization between the common bleak and Iberian fish species, already emphasized by several authors (Robalo et al. 2006, Vinyoles et al. 2007, Perea et al. 2010) and already reported by Almodóvar et al. (2012) for the Tagus River basin, prompted a study on the impact of Alburnus alburnus on populations of the Spanish minnowcarp, Anaecypris hispanica (Steindachner, 1866), locally known as saramugo, from the Guadiana River basin, as part of a LIFE project targeting the conservation of this endemic species (project reference: LIFE13/ NAT/PT/000786-Saramugo). Anaecypris hispanica is included in the Annexes II and IV of the European Union Habitats Directive* and in Appendix III of the Bern

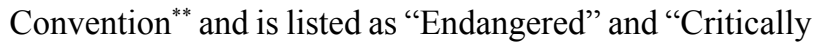
Endangered", respectively, in the IUCN Red List of Threatened Species (Crivelli 2006) and in the Portuguese Red data Book of Vertebrates (Cabral et al. 2005). This species currently faces a declining population trend, with local extinctions reported mainly due to pollution, habitat loss, water scarcity, damming, and proliferation of exotic species (Doadrio 2001, Sousa-Santos et al. 2014). Besides Anaecypris hispanica, the Guadiana River basin harbours six other endemic cyprinid species, five of them with high conservation status (Cabral et al. 2005): Pseudochondrostoma willkommii (Steindachner, 1866) and Squalius alburnoides (Steindachner, 1866) ("Vulnerable"); and Luciobarbus sclateri (Günther, 1868); Luciobarbus comizo (Steindachner, 1864); and Iberochondrostoma lemmingii (Steindachner, 1866) ("Endangered").

Anaecypris hispanica, as well as Squalius pyrenaicus (Günther, 1868) and Squalius alburnoides, are proven to be phylogenetically close to Alburnus alburnus (see Robalo et al. 2006, Levy et al. 2008), increasing the risk of intergeneric hybridization for these three native species occurring in the Guadiana River. Other potentiating factors are added to the phylogenetic relatedness, such as the partially overlapping breeding seasons (Ribeiro et al. 2000, Almeida et al. 2014), during which fish may be spatially confined (in summer, the Mediterranean-type Guadiana River is typically reduced to a series of more or less disconnected pools); identical habitat preferences (Ribeiro et al. 2000, Ilhéu et. al 2016, Matono et al. 2018); and the disproportionally higher local densities represented by the large dimension shoals of Alburnus alburnus (see Ilhéu et al. 2016) when compared with the generally depleted and fragmented native populations. The potential hybridization with Alburnus alburnus would result in the introgression of alien genes in the genetic pool of native species, resulting in the loss of their taxonomical integrity and other unpredictable consequences.

The hybridization between Alburnus alburnus and Anaecypris hispanica will undoubtedly raise major concerns if these conditions are met simultaneously: longlasting sympatric occurrence, synchronic breeding seasons, compatible gametes, and fertile hybrid offspring. A proper evaluation of the new potential threat for the conservation of the highly endangered Anaecypris hispanica is thus needed as well as the assessment of natural occurring hybrids between other native fish species and the invasive Alburnus alburnus, in the Guadiana River basin. As such, the aim of this study was to improve the current knowledge by 1) evaluating the presence of hybrids with Alburnus alburnus in the wild, using molecular screening of individuals with intermediate morphologies and 2) testing if artificial crosses between Alburnus alburnus and Anaecypris hispanica resulted in viable hybrid offspring. To achieve these goals, the genetic profile of Alburnus alburnus occurring in the Guadiana and Sado rivers was established using two molecular markers (cytochrome $b$, latter referred to as cyt $b$ and beta-actin genes) to allow comparisons with the profiles of the three sympatric species with which it could potentially hybridize (Anaecypris hispanica, Squalius alburnoides, and Squalius pyrenaicus). This profile was further used to assess if fish identified in the field as hybrids due to their intermediate morphological features were indeed hybrids. Finally, artificial crosses between Alburnus alburnus and Anaecypris hispanica were conducted to test the compatibility of their gametes and the viability of the offspring.

\footnotetext{
https://eur-lex.europa.eu/eli/dir/1992/43/oj.

"https://rm.coe.int/CoERMPublicCommonSearchServices/DisplayDCTMContent?documentId=0900001680304356.
} 


\section{MATERIALS AND METHODS}

Sampling. Field surveys were conducted by electrofishing in the Sado River (Alcáçovas sub-basin; $\left.38^{\circ} 26^{\prime} 34.27^{\prime \prime} \mathrm{N}, 8^{\circ} 05^{\prime} 47.69^{\prime \prime} \mathrm{W}\right)$ and in the Guadiana River (XévoraandCaiasub-basins; $39^{\circ} 03^{\prime} 37.63^{\prime \prime} \mathrm{N}, 7^{\circ} 00^{\prime} 21.50^{\prime \prime} \mathrm{W}$ and $39^{\circ} 07^{\prime} 32.66^{\prime \prime} \mathrm{N}, 7^{\circ} 16^{\prime} 51.38^{\prime \prime} \mathrm{W}$, respectively), under the scope of the LIFE Saramugo project (LIFE13/NAT/ $\mathrm{PT} / 000786$ ), in 2015 and 2016. Permits for field work were given by the ICNF, the National Institute for the Conservation of Nature and Forests. Captured individuals, showing intermediate morphological features, were identified as potential hybrids $(n=26)$, measured for fork length (FL), and brought to the lab after being euthanized by freezing. The number of scales of the lateral line (SLL) of these intermediate specimens was counted to test if this meristic character, which is distinct among the potentially hybridizing species (38-44 for Squalius alburnoides, 59-71 for Anaecypris hispanica, and 47-52 for Alburnus alburnus) (Doadrio et al. 2011), could be used in the future for an expedite recognition of hybrids in the wild.

Fin clips were collected from potential hybrids and from 15 specimens of Alburnus alburnus preserved for diet studies under the above-mentioned project. Tissue samples were preserved in $96 \%$ ethanol and stored at the collection of the MARE-ISPA for subsequent DNA extraction, amplification and sequencing.

DNA analyses. Total genomic DNA was extracted from fin clips using REDExtract-N-Amp Tissue PCR kits (Sigma-Aldrich), following the manufacturer's instructions. The mitochondrial cytochrome $b$ (cyt $b$ ) and the nuclear beta-actin genes were amplified using the primers and conditions described in Sousa-Santos et al. (2014). PCR products were purified and sequenced in the forward direction at Stabvida (FCT, Portugal). The obtained sequences were aligned using the CodonCode Aligner v4.0.4 software (CodonCode Corp., USA) and deposited in GenBank. The search for shared haplotypes and the listing of representative sequences was conducted by DNAcollapser (FaBox v.1.41*).

In order to build a reference library for each molecular marker, the newly obtained sequences of Alburnus alburnus from the Guadiana River (cytb: $n=15$; betaactin: $n=7$ ) were grouped with sequences of Alburnus alburnus from other Euro-Asian river basins (cyt $b$ : $n=$ 6; beta-actin: $n=1$ ) and of the sympatric species from the Guadiana River with which Alburnus alburnus could potentially hybridize: Anaecypris hispanica (cytb: $n=1$; beta-actin: $n=159,29$ haplotypes), Squalius pyrenaicus (cytb: $n=1$; beta-actin: $n=9$, six haplotypes), and Squalius alburnoides (cyt $b: n=1$; beta-actin: $n=20$, eight haplotypes) (Table 1). Accession numbers of all the sequences were included in Table 1.

Although the phylogeny of Alburnus alburnus was already described elsewhere (Levy et al. 2008, Perea et al. 2010), a phylogenetic tree was drawn to assess the phylogenetic positioning of the A. alburnus individuals from the Guadiana River, based on cyt $b$ gene sequencing. Phylogenetic relations were reconstructed by maximum parsimony using PAUP 4.0 (Swofford 1998). Branch

Sequences used to build the reference libraries for both molecular markers used (cyt $b$ and beta-actin), with which the studied Alburnus alburnus individuals were compared

\begin{tabular}{|c|c|c|c|c|}
\hline Species & $\begin{array}{l}\text { River basin, } \\
\text { Country }\end{array}$ & $\begin{array}{c}\text { Cyt } b \text { GenBank } \\
\text { accession number }\end{array}$ & Beta-actin GenBank accession number & Reference \\
\hline Anaecypris hispanica & Guadiana, Portugal & AJ427834 & KM435483-KM435725 & $\begin{array}{l}\text { Alves et al. 2001b } \\
\text { Sousa-Santos et al. } 2014\end{array}$ \\
\hline Squalius alburnoides & Guadiana, Portugal & AJ427837 & $\begin{array}{l}\text { AA genomotype: DQ263227, } \\
\text { DQ263229, EF458779-81, EF458783, } \\
\text { EF458788-89, EF458792 } \\
\text { PA genomotypes: DQ263230-31, } \\
\text { EF458785 } \\
\text { PAA genomotypes: DQ263228, } \\
\text { DQ263232-33, EF458782, EF458784, } \\
\text { EF458786-87, EF458797 }\end{array}$ & $\begin{array}{l}\text { Alves et al. } 2001 \mathrm{~b} \\
\text { Sousa-Santos et al. } 2005 \text {, } \\
2006\end{array}$ \\
\hline Squalius pyrenaicus & Guadiana, Portugal & DQ263236 & $\begin{array}{l}\text { DQ150279-80, DQ150327-32, } \\
\text { DQ150323-24, } \\
\text { DQ150272-73, AY943877 }\end{array}$ & $\begin{array}{l}\text { Sousa-Santos et al. 2006a, } \\
2006 \mathrm{~b}\end{array}$ \\
\hline Alburnus alburnus & Guadiana, Portugal & MH141602-616 & MH141618-23 & This study \\
\hline Alburnus thessalicus & Pinios, Greece & AF090744 & - & Zardoya and Doadrio 1999 \\
\hline Alburnus alburnus & Strymon, Greece & AF090745 & - & Zardoya and Doadrio 1999 \\
\hline Alburnus alburnus & Croatia & DQ350254 & MH141617 & GenBank and this study \\
\hline Alburnus thessalicus & $\begin{array}{l}\text { Elbe, Czech } \\
\text { Republic }\end{array}$ & HM560060 & - & Perea et al. 2010 \\
\hline Alburnus alburnus & Sinhuka, Russia & HM560062 & - & Perea et al. 2010 \\
\hline Alburnus alburnus & Jarama, Spain & JQ436541 & - & Almodóvar et al. 2012 \\
\hline
\end{tabular}


support was assessed by bootstrap analyses using 1000 replicates and Cyprinus carpio Linnaeus, 1758 as outgroup (GenBank accession number: DQ868875).

Concerning the beta-actin nuclear gene, which allows for the identification of hybrids as alleles inherited by both parents, sequences of heterozygous individuals were analysed according to the procedures described in SousaSantos et al. (2005) and single nucleotide polymorphisms were integrated in the reference library of haplotypes along with the sequences of Squalius pyrenaicus, Anaecypris hispanica, and Squalius alburnoides. As this latter species is in fact a polyploid complex which arose from intergeneric hybridization between Squalius pyrenaicus females (PP genome) and males from an already extinct Anaecypris-like species (AA genome), its beta-actin profile is hybrid, reflecting various combinations of the parental genomes (genomotypes): PAA, PPA, PPAA, PAAA, PA, and AA (Alves et al. 2001a, Morgado-Santos et al. 2016). As such, beta-actin sequences of the most common genomotypes occurring in the Guadiana River were included in the reference library: AA, PA, and PAA (Table 1). The method described by Sousa-Santos et al. (2005) and already used successfully to identify Squalius alburnoides genomotypes (Sousa-Santos et al. 2006a, 2006b, 2007) was also applied to assess the genome constitution of the hybrids involving this species. These results, combined with the information on the reproductive modes known for the Squalius alburnoides complex (Alves et al. 2001a), allowed the extrapolation of the genomotype of the $S$. alburnoides mother/father of the identified hybrid individuals.

In those cases where unambiguous calling the bases of both genetic complements was not possible, the nucleotide ambiguity code was used to map the mutations present in beta-actin haplotypes. Trimming the $3^{\prime}$ ends of all the sequences was adopted as a caution measure so that the portion of the fragment where typically a loss of signal occurs was not considered for a reliable identification of the called bases. Finally, the polymorphic sites of the betaactin gene were resumed in a table of differences using the CodonCode Aligner software and used as speciesdiagnostic loci to allow for the detection of hybrids.

Fertilization experiments. Artificial crosses between Alburnus alburnus and Anaecypris hispanica were conducted using, respectively, individuals captured in the field during the breeding season (between May and July, in the rivers Caia and Degebe; Ilhéu et al. 2016) and individuals maintained at ex-situ conservation facilities located at the "Parque Natural do Vale do Guadiana". Fish were sorted according to their maturation stage, which was assessed by applying a slight pressure on the abdomen. Only the females which released gametes during this procedure were used for the artificial crosses to obviate the use of immature oocytes. Oocytes of one species were gently mixed with sperm from the other species, in distinct Petri dishes to which $10 \mathrm{~mL}$ of water tank was added. After $10 \mathrm{~min}$, the eggs of each Petri dish were transferred into small tanks $(1 \mathrm{~L})$ with permanent aeration and methylene blue $(\sim 0.5 \mathrm{~mL})$ to avoid fungal contamination. After $24 \mathrm{~h}$, a small portion of the eggs was carefully removed from the tank and inspected under a binocular microscope to check for evidence of successful fertilization. Each day, eggs showing signs of fungal contamination were individually removed from the tank to avoid the contamination of the whole batch. This procedure was replicated in the four trials conducted during the reproductive season of 2015 and 2016. The number of males and females used in each trial differed according to the number of mature individuals available and the number of gametes released. All fish survived the procedure and were returned live to their respective maintenance tank.

Simple descriptive statistics were conducted using Microsoft Excel.

The presently reported study was carried on in accordance with the Portuguese state regulation and fieldwork permits were obtained from the National Institute for the Conservation of Nature and Forests (ICNF), Portugal.

\section{RESULTS}

DNA analyses. Sequencing of the mitochondrial cyt $b$ and nuclear beta-actin genes resulted in aligned fragments of 991 and $405 \mathrm{bp}$, respectively. Cyt $b$ gene sequencing of the Alburnus alburnus individuals $(n=15)$ yielded four haplotypes (ALBURN1-4), differing only by 1 to 5 mutations (Table 2), which accounts for $0.10 \%$ to $0.50 \%$ of pairwise divergence among sequences.

The phylogenetic tree, based on the analysed cyt $b$ gene fragment (with 168 parsimony informative loci out of a total of 278 variable sites), showed that Alburnus alburnus is more closely related to Anaecypris hispanica than to the sympatric Squalius species (Fig. 1). One of the Alburnus alburnus haplotypes from the Guadiana River (ALBURNCYT3) is shared with the Jarama River (Spain). These and the remaining Alburnus alburnus haplotypes from Guadiana River group with one haplotype from the Czech Republic forming a well-supported clade, which is clearly distinct from that from Russia, Croatia, and Greece (Fig. 1).

Table 2

Relative frequencies ( $n$ ) of cytb haplotypes of Alburnus alburnus from the Guadiana River found and number of pairwise differences between each pair of haplotypes

\begin{tabular}{lrccc}
\hline & $n$ & ALBURNCYT1 & ALBURNCYT2 & ALBURNCYT3 \\
\hline ALBURNCYT1 & 10 & & & \\
ALBURNCYT2 & 1 & 1 & 5 & \\
ALBURNCYT3 & 3 & 4 & 4 & 1 \\
ALBURNCYT4 & 1 & 3 & & \\
\hline
\end{tabular}


Regarding beta-actin gene sequencing, 12 haplotypes were identified among sequences of Alburnus alburnus from the Guadiana River $(n=7)$ and Croatia $(n=1)$, with only three of them being found in homozygosity (Table 3). These haplotypes and the ones obtained for Squalius alburnoides, Anaecypris hispanica, and Squalius pyrenaicus, integrated the reference library built for the beta-actin gene (Table 3). The inspection of the reference library shows 15 species-diagnostic loci, i.e., point mutations which are shared by all the individuals of a given species, which were used to distinguish sympatric species from the Guadiana River at the nuclear DNA level. Detection of hybrids with Alburnus alburnus in the wild. A total of 26 potential hybrids were identified in the field based on intermediate morphological features, in the following sub-basins of the Guadiana and Sado river basins: Xévora $(n=13)$, Caia $(n=10)$, and Alcáçovas $(n=$ 3 ). These individuals were primarily identified as Squalius alburnoides but with atypical coloration and head and pelvic fin profiles and represented $26 \%$ and $50 \%$ of the total number of $S$. alburnoides captured in these sampling sites from the Guadiana River basin ( $n=50$ in Xévora and $n=20$ in Caia, respectively). The total number of Squalius alburnoides captured in the Alcáçovas sub-basin was not recorded. The mean fork length ( \pm standard deviation) was of $84.42 \pm 12.15 \mathrm{~mm}(64-113 \mathrm{~mm})$ and the number of scales of the lateral line (SLL) was $49.27 \pm 2.95$ (44-57).

The cyt $b$ gene sequencing results showed that 23 individuals had Alburnus alburnus mtDNA while the remaining three had Squalius pyrenaicus mtDNA (Table 4). Beta-actin gene sequencing was not possible for four individuals (likely due to the degradation of the nuclear
DNA of these samples) but out of the 22 individuals sequenced, six (27\%) were hybrids between Squalius alburnoides and Alburnus alburnus and the remaining 16 individuals were A. alburnus, homozygous $(n=11)$ or heterozygous $(n=5)$ for the considered gene fragment (Table 4). Photos from the hybrids and from pure Squalius alburnoides and Alburnus alburnus are shown in Fig. 2.

Combining the results of both markers and looking to the nature of the maternally inherited sequence, it is possible to identify that hybrids resulted from crosses between Squalius alburnoides females and Alburnus alburnus males ( $n=3$; two from Caia and one from Xévora) and from the reciprocal cross, i.e., between Squalius alburnoides males and $A$. alburnus females ( $n=3$; two from Caia and one from Alcáçovas) (Table 4). Considering the beta-actin profiles of the hybrids and the reproductive modes known for the Squalius alburnoides complex, it was possible to predict the parental genomotypes: all the $S$. alburnoides females involved in the hybrid crosses with Alburnus alburnus had a SAA genomotype, while all the males involved in the reciprocal hybrid crosses were Squalius alburnoides with a AA genomotype (Table 4). Regarding the number of scales of the lateral line, these hybrids had $47.3 \pm 2.1$ scales (mean $\pm \mathrm{SD}$ ) (44-50), while the non-hybrids had $49.4 \pm 2.2$ scales (mean \pm SD) (47-54); for the values obtained for each individual see Table 4.

Artificial crosses between Alburnus alburnus and Anaecypris hispanica. Four trials of crosses between Anaecypris hispanica females and Alburnus alburnus males and three trials of the reciprocal cross were conducted, involving a total of 69 gamete-donor fish (Table 5).

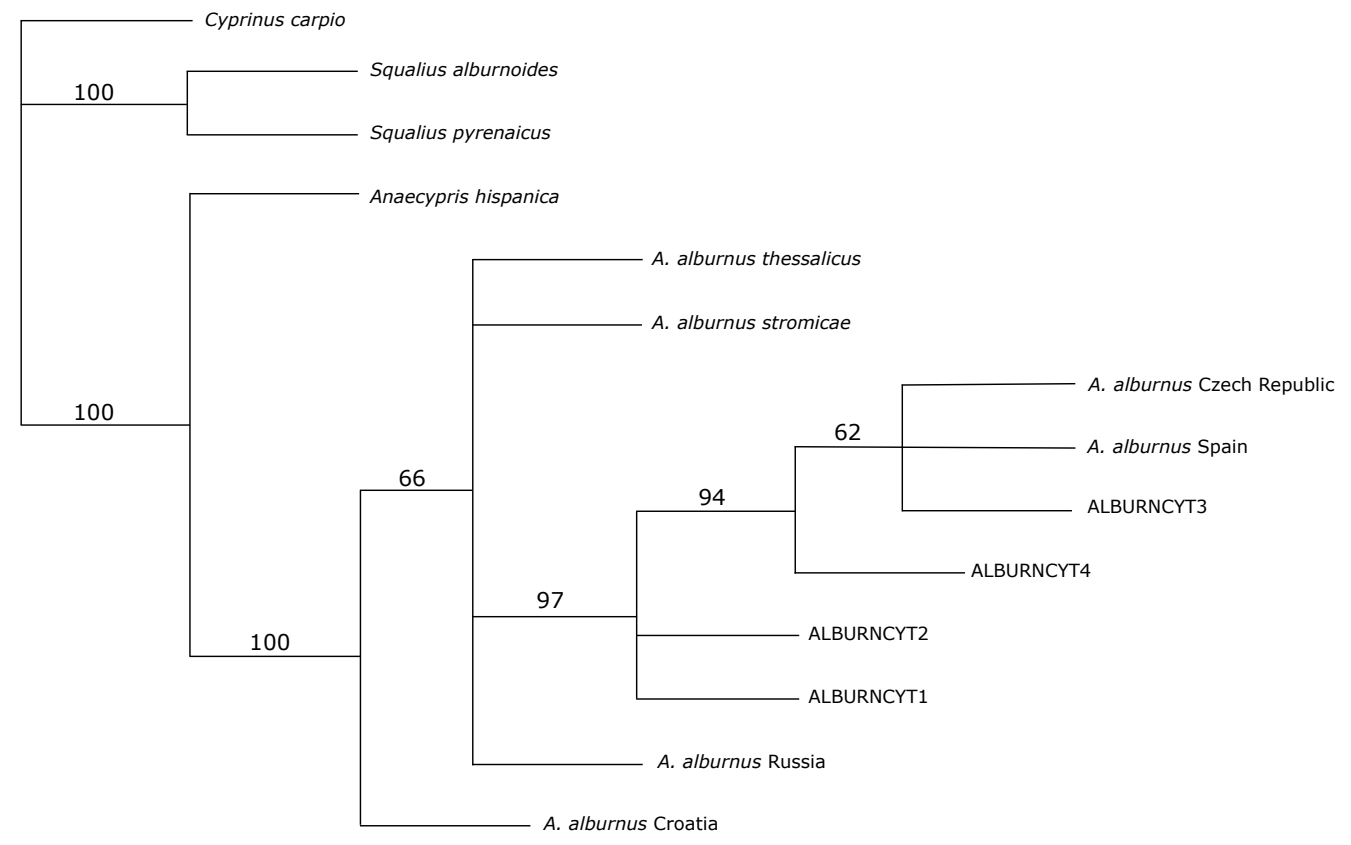

Fig. 1. Schematic representation of the parsimony tree illustrating the phylogenetic relations among sampled Alburnus alburnus based on cytb gene sequences; bootstrap values are indicated for each well supported node (60\% majority rule); sequences of Anaecypris hispanica, Squalius alburnoides, Squalius pyrenaicus, and Cyprinus carpio (outgroup) were also included in the tree 


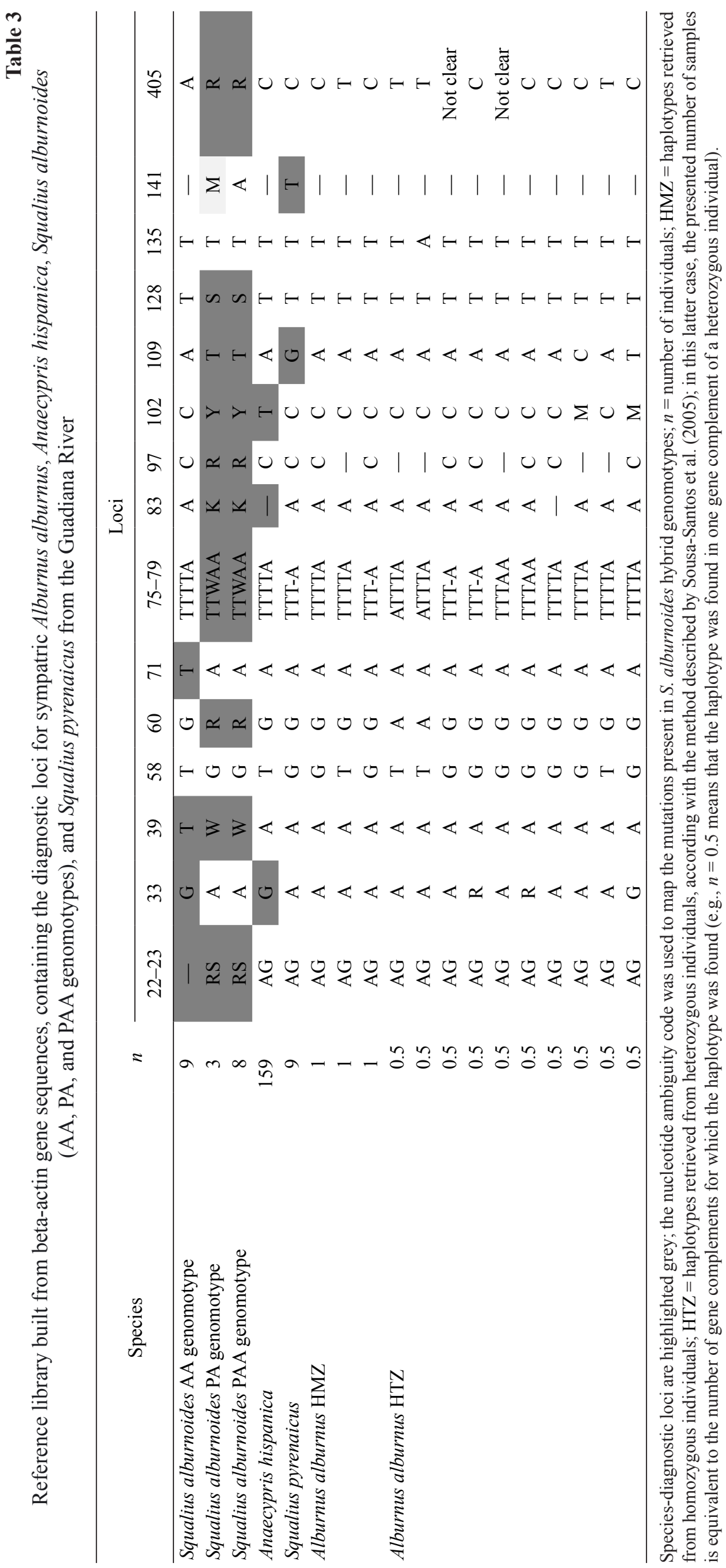




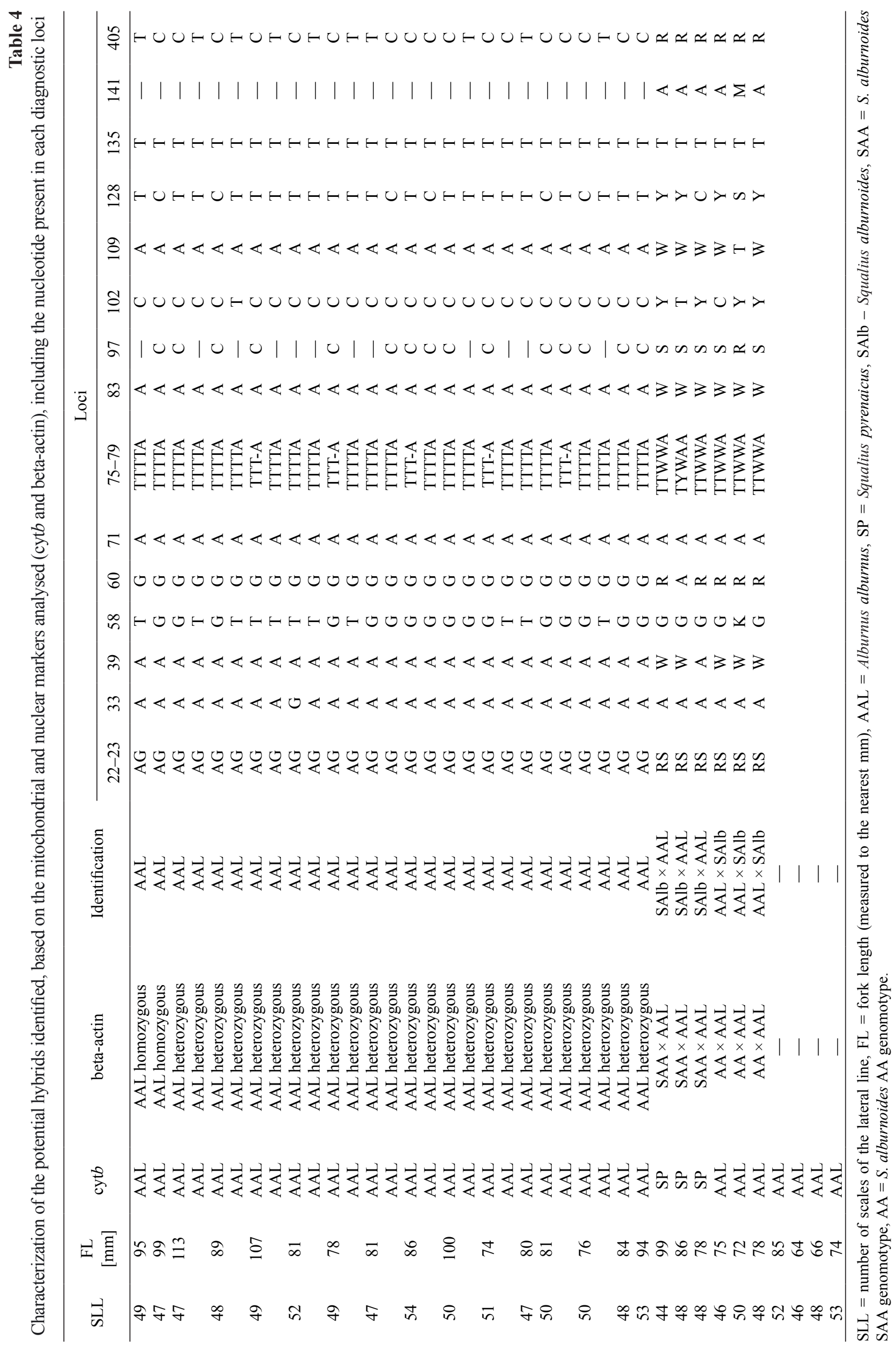



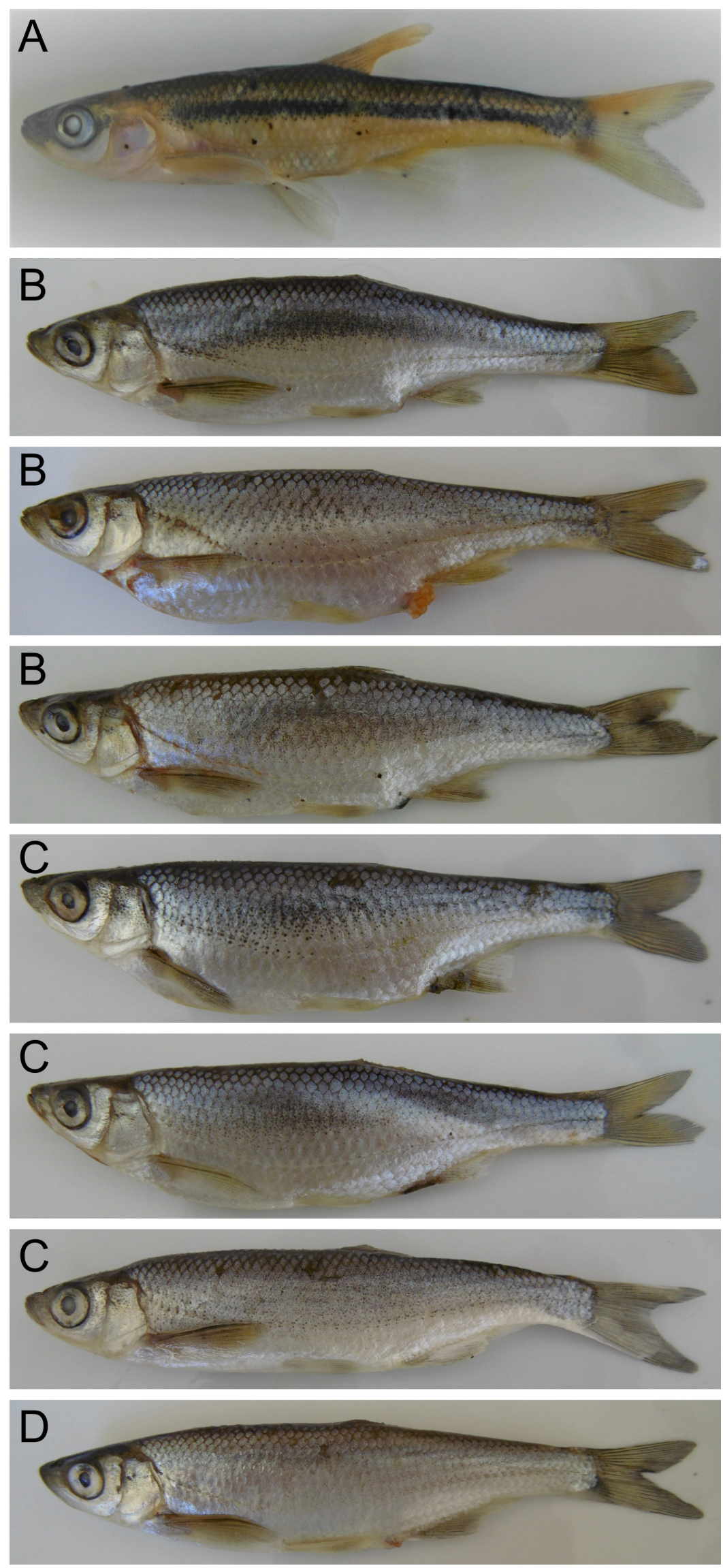

Fig. 2. Photographs of Squalius alburnoides, Alburnus alburnus, and their hybrids; S. alburnoides (A), S. alburnoides* $\times$ A. alburnus hybrids $(\mathbf{B})$, A. alburnus $* \times$ S. alburnoides hybrids $(\mathbf{C})$, A. alburnus $(\mathbf{D})$; the asterisk $(*)$ indicates the mother species of the hybrid, based on mitochondrial DNA results 
Table 5

Experimental crosses between Alburnus alburnus and Anaecypris hispanica made with the artificial fertilization of eggs from one species with the sperm of the other species

\begin{tabular}{llccc}
\hline \multicolumn{1}{c}{ Artificial cross } & \multicolumn{1}{c}{ Date } & $\begin{array}{c}n \\
\text { females }\end{array}$ & $\begin{array}{c}n \\
\text { males }\end{array}$ & $\begin{array}{c}n \\
\text { eggs }\end{array}$ \\
\hline A. hispanica females $\times$ A. alburnus males & Jun 2015 & 6 & 2 & 7 \\
& 25 May 2016 & 5 & 1 & 68 \\
A. alburnus females $\times$ A. hispanica males & 8 Jun 2016 & 4 & 11 & 11 \\
& 20 Jun 2016 & 5 & 5 & 107 \\
& 25 May 2016 & 1 & 3 & $40 \mathrm{VE}$ \\
& 8 Jun 2016 & 1 & 10 & $50 \mathrm{VE}$ \\
& 20 Jun 2016 & 1 & 14 & $100 \mathrm{VE}$ \\
\hline
\end{tabular}

$n=$ number of specimens, $\mathrm{VE}=$ visual estimate.

In total, over 186 oocytes of 20 Anaecypris hispanica females and over 190 oocytes of three Alburnus alburnus females were fertilized by sperm from19 Alburnus alburnus and 27 Anaecypris hispanica males, respectively. Although the clear distinction between the core and peripheral areas of the oocytes indicated the occurrence of fertilization and of the first divisions of the egg, all eggs were considered unviable $24-48 \mathrm{~h}$ after fertilization.

\section{DISCUSSION}

The high incidence of hybridization in fish seems to be a result of several contributing factors: external fertilization, weak behavioural isolating mechanisms, unequal abundance of the parental species, competition for limited adequate spawning habitat, decreasing habitat complexity, and susceptibility to secondary contact between recently evolved forms (reviewed by Scribner et al. 2001, Hernández Chávez and Turgeon 2007). Hybrids between distantly related fish species are also frequently viable since fish appear to be less susceptible to severe developmental incompatibilities that affect interspecific hybrids between other vertebrate taxa (Scribner et al. 2001). The risk of interspecific hybridization and the assessment of its extent is often an underappreciated problem but the more frequent use of molecular tools in biological assessments may contribute to change this reality (Rhymer and Simberloff 1996).

The non-native population of Alburnus alburnus, introduced to Portugal, in the Guadiana River basin, around 12 years ago (Vinyoles et al. 2007), presents some haplotype diversity for the mitochondrial cyt $b$ gene, with haplotypes that closely resemble those found in Alburnus alburnus from Spain and the Czech Republic. Moreover, a shared haplotype with an individual from the Spanish Tagus (Jarama River) suggests that the stock introduced in the Guadiana and Tagus River basins could have had the same provenience. Our results corroborate the close phylogenetic proximity between Alburnus alburnus and Anaecypris hispanica already described by other authors, as well as a wider distance to the sympatric Squalius species: S. pyrenaicus and S. alburnoides (see Levy et al. 2008, Perea et al. 2010). Despite the closest phylogenetic affinity between Alburnus alburnus and Anaecypris hispanica, natural occurring hybrids between these two species were yet not detected and the artificial crosses conducted during this study did not result in viable offspring. Contrastingly, the less phylogenetically related Squalius alburnoides hybridizes in the wild with Alburnus alburnus in at least three Iberian river basins: Sado, Guadiana, and Tagus (Almodóvar et al. 2012 and this study). As such, it seems clear that phylogenetic relatedness, if traduced in the absence of pre- and post-zygotic barriers to reproduction, is essential for hybridization. However, as shown in the presently reported study, phylogenetic relatedness by itself does not necessarily implies the occurrence of hybridization between the bleak and all the closely related native cyprinids with which it becomes sympatric along its invasive path. Other characteristics such as the preference for similar spawning grounds, synchronous spawning seasons, responsiveness to the same courting behaviours, and similar body size of adults are most likely the main factors that are essential for hybridization to occur. One should also expect that the magnitude of the hybridization events, which may range from the occurrence of rare and punctually-located hybrid individuals to a massive production of hybrids which may widespread and replace their parental species at a river basin scale, will likely depend on the similarity of the previously listed essential factors. Importantly to note, however, is that both the frequency and the magnitude of the hybridization events will most likely vary in time and space in response to changes potentially occurring in the factors which promote them. This means that if there are no reproductive barriers to hybridization between two species, the absence of naturally occurring hybrids at some point in time does not necessarily means that they will never occur nor that, once detected, their abundance will always show stabilized values. For instance, the preferred spawning grounds may shift in response to habitat destruction or degradation; the spawning seasons may become more synchronous due to climate change; and previously not attractive courting behaviours may later trigger positive responses as a result of the natural evolution process of the species. Thus, it becomes clear that the occurrence of Alburnus alburnus $\times$ Squalius alburnoides hybrids in low frequencies and the apparent absence of hybridization with Anaecypris hispanica should not be considered as immutable facts. 
Regarding the highly endangered Anaecypris hispanica, it is important to conduct further studies to test the absence of barriers to reproduction with Alburnus alburnus. Indeed, it seems that these species are not hybridizing in the wild, at least so far, likely due to the absence of spatial sympatry (they do not coexist yet, after prospections made between 2015 and 2016 in more than 50 sampling sites; Ilhéu et al. unpublished data) and to the extremely low densities of Anaecypris hispanica populations (Cardoso et al. 2015). Eggs or larvae were also not found in the tanks where Alburnus alburnus and Anaecypris hispanica were kept for 3-4 months, over two consecutive reproductive seasons (May through July 2015 and April through July 2016), to study their behaviour in sympatry (da Silva et al. unpublished*). These observations were made during a preliminary study involving three groups of 15 Alburnus alburnus and 30 Anaecypris hispanica kept in three aerated outdoor tanks supplied with clay tiles for sheltering fishes.

Still, in the case of disruption of the above suggested constraints to sympatry in the wild, our results point to a likely unviability of the hybridization between Alburnus alburnus and Anaecypris hispanica: although there was evidence of fertilization, the further development of about 400 eggs was not accomplished in all the interspecific cross trials conducted. This result may be explained by one of the following hypotheses: 1) a chromosomal incompatibility between the two species prevents the normal development of the egg after its first mitotic divisions; 2) methodological aspects and the conditions under which fertilization and egg maintenance were made were inadequate; and 3) immature oocytes were used instead of spontaneous laid ones. Thus, the null hypothesis of crosses between Alburnus alburnus and Anaecypris hispanica do not result in the production of viable offspring may not be fully discarded.

Concerning the hybrids detected in the wild, the developed protocol using a combination of 15 diagnostic nuclear loci and mtDNA sequencing, showed not only that Alburnus alburnus is already hybridizing in the wild with a sympatric native species, Squalius alburnoides, but also that these hybridization events are bidirectional and give rise to viable hybrid adults with at least $2-3$ years old (considering the fork length of the sampled individuals). The participation of females of both species in the interspecific crosses explains the detection of Alburnus alburnus and Squalius pyrenaicus mtDNA in the hybrid individuals (Fig. 3).

It was also possible to determine that the Squalius alburnoides genomotypes which hybridized with Alburnus alburnus were PAA females and AA males, the most common genomotypes found in the Guadiana River (Alves et al. 2001a). In both cases, the produced gametes are haploid (by normal meiosis in the case of AA males and by hybridogenetic meiosis in the case of the PAA females, which exclude the P-genome prior to the meiosis; Alves et al. 2001a), thus the resulting hybrids with Alburnus alburnus are diploid individuals with a AB genomotype (Fig. 3).
It is worth mentioning that from the 22 individuals captured in the Guadiana and Sado rivers, identified as potential hybrids between Squalius alburnoides and Alburnus alburnus due to their intermediate morphological features and sequenced for both molecular markers, only six $(27.3 \%)$ were indeed hybrids between those two species. The number of scales of the lateral line (SLL) of the analysed hybrids (44-50) was intermediate between the SLL of the parental species (38-44 for Squalius alburnoides and 47-52 for Alburnus alburnus; Doadrio et al. 2011) although some superimposition of ranges was detected. Thus, despite being considered one of the main diagnostic characters of Alburnus $\times$ Squalius hybrids (Almodóvar et al. 2012), the use of SLL, which could be an easily used featured in the field, does not allow for a reliable identification of Alburnus alburnus and Squalius alburnoides hybrids, at least in the sampled river basins. Our results clearly demonstrate the need to rely on molecular rather than in morphological identifications,
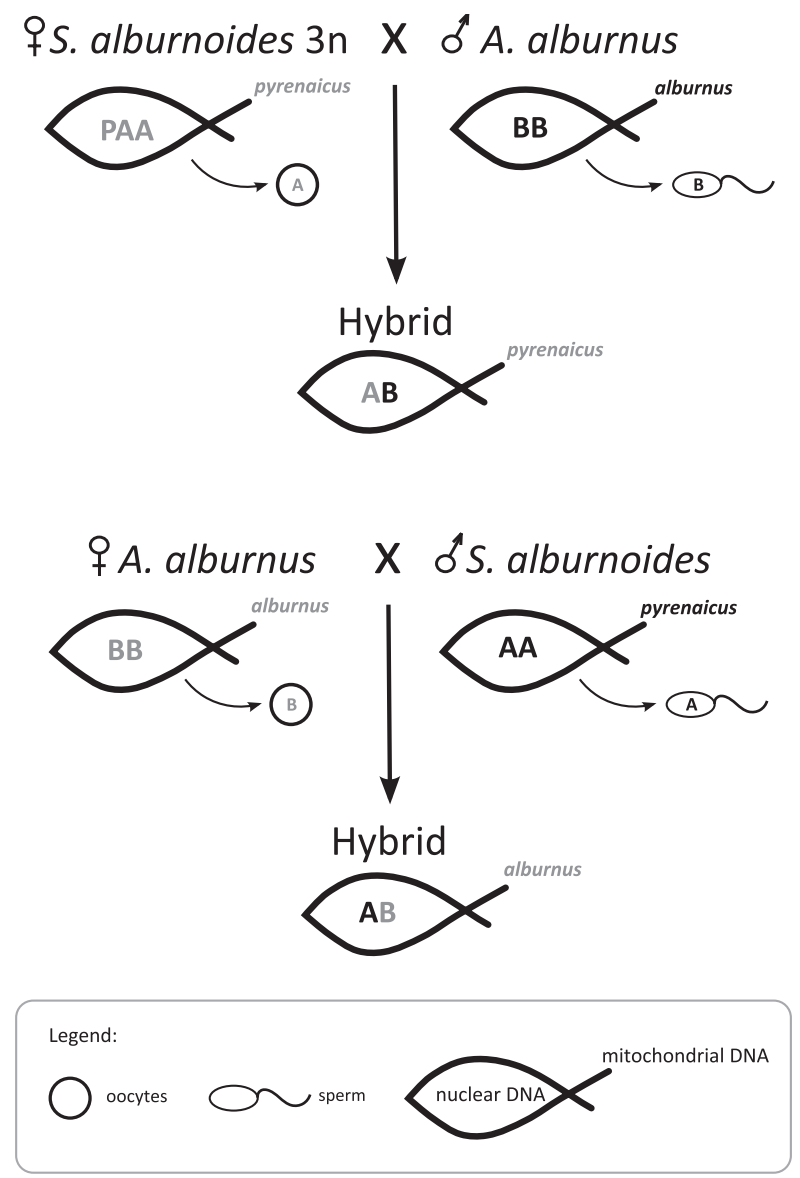

Fig. 3. Schematic representation of the hybridization between Squalius alburnoides and Alburnus alburnus, described in this study, with the identification of the mitochondrial DNA and nuclear genomotypes of the hybrid individuals sequenced; legend of the genotypic complements: $\mathrm{P}=S$. pyrenaicus, $\mathrm{A}=S$. alburnoides, $\mathrm{B}=$ A. alburnus 
using at least one mitochondrial and one nuclear marker. This approach was already suggested for the cryptic but frequent intrageneric hybrids of Luciobarbus from Guadiana River (Sousa-Santos et al. 2018).

If the proliferation of the bleak progresses towards the last refugia of the critically endangered Anaecypris hispanica (now occurring in extremely low densities in very small areas scattered along five Guadiana River tributaries; Sousa-Santos et al. 2014), a scenario of sympatry between Alburnus alburnus, Anaecypris hispanica, and Squalius alburnoides would be probable. Under this hypothetical scenario, hybridization with Squalius alburnoides would be expectedly privileged due to the high density of their populations (when compared to the rarefied populations of Anaecypris hispanica) and to the more similar body size (Anaecypris hispanica rarely reaches a maximum body length of $10 \mathrm{~cm}$, in contrast to the $13 \mathrm{~cm}$ of Squalius alburnoides and $15 \mathrm{~cm}$ of Alburnus alburnus; Doadrio et al. 2011). However, if the hybridization between Alburnus alburnus and Anaecypris hispanica becomes viable in the wild (the absence of reproductive isolation, as mentioned above, could not be fully discarded in the presently reported study), this could likely result in a serious aggravation of the declining trend or even local extinctions of the native species. This expectation in supported by 1) the probable shifts in the environmental conditions leading to a higher confinement of both species in space and time, during the reproductive season, due to the intensification of summer droughts in temporary Mediterranean streams (Lehner et al. 2006, Anonymous 2012, Robson et al. 2013); and 2) the fact that ethological observations of mixed groups in the same experimental tanks, showed that Anaecypris hispanica individuals do not react to Alburnus alburnus with avoidance behaviours but rather with a higher activity and a wider occupation of the available space (Ilhéu et al. 2016, da Silva et al. unpublished*). Thus, in the case of a strong confinement in summer pools, the presence of a high number of Alburnus alburnus reproductive males would likely result in a lower probability of Anaecypris hispanica females crossing with conspecifics and in the consequent lower recruitment of the native species. If this situation continued for some generations, it could lead to the short-term extinction of Anaecypris hispanica. Also, if the hybrid offspring were fertile and ecologically successful, Anaecypris hispanica could be displaced or eliminated by the resultant hybrid complex, as reported for other hybridizing fish species (e.g., Konishi and Takata 2004, Rosenfield et al. 2004). This outcome was also predicted to explain the extinction of the paternal ancestor of the hybridogenetic complex Squalius alburnoides: the maternal species of the complex (Squalius pyrenaicus) likely hybridized massively with the paternal species, generating hybrid individuals with larger body size, with higher fecundity and ecologically more adapted than their paternal ancestors (Robalo et al. 2006, Sousa-Santos et al. 2007). The fundamental difference between this scenario and the one hypothesized for an eventual massive hybridization event between Alburnus alburnus and Anaecypris hispanica is that the Squalius alburnoides complex was most likely originated as a result of a contact between previously allopatric populations due to rearrangements of Iberian paleobasins (Sousa-Santos et al. 2007) and not due to an anthropogenic-mediated event.

In conclusion, all the above expectations require deeper investigations which fall beyond the scope of the present paper. However, the conducted study raised awareness about the impact that the proliferation of an invasive species may impose to the conservation of phylogenetically related native species, by threatening their taxonomical integrity which may, ultimately, lead to its displacement or extinction by the resultant hybrids - a process which may be achieved in a small timescale (Epifanio and Philipp 2000). A higher risk of hybridization with invasive species is potentially linked with climate change, as recently reported by Muhlfed et al. (2014). These authors showed that decreases in spring precipitation and increases in summer stream temperature over a 30-year period had promoted the upstream expansion of the non-native rainbow trout, Oncorhynchus mykiss (Walbaum, 1792), and the consequent increase of hybridization with the endangered native westslope cutthroat trout, Oncorhynchus clarkii clarkii (Richardson, 1836), in North America, highlighting the fact that climate warming may indeed exacerbate hybridization between native and non-native species, which can result in the extinction of many species. Thus, in order to effectively contribute to the conservation of native fish species in temporary river systems invaded by exotic species, it is crucial to invest in standardized and continued ecological and genetic monitoring which can produce reliable data regarding the identification of cryptic hybrids and the detection of eventual shifts in environmental conditions and life history traits that promote hybridization events. In parallel, there is an obvious need to implement management measures that result in an effective mitigation of invasive species proliferation or, ideally, in its complete eradication and to invest in the rehabilitation of summer refugia for native fish, contributing to the preservation of the Mediterranean as one of the main hotspots for global biodiversity.

\section{ACKNOWLEDGEMENTS}

We would like to thank Carlos Carrapato, from the National Institute for the Conservation of Nature and Forests (ICNF) for providing the necessary conditions at the Guadiana River Valley Natural Park (PNVG) facilities, for the artificial fertilization trials and the use of Anaecypris hispanica specimens. Thanks are also due to all the colleagues involved in the fieldwork for the capture of Alburnus alburnus used in the trials. This study was funded by the European Union LIFE program (LIFE13/ NAT/PT/000786-Saramugo); the Fundação para a Ciência e Tecnologia (FCT) of Portugal, through the strategic project UID/MAR/04292/2013 granted to MARE; and the grant awarded to C. Sousa-Santos (MARE-ISPA/ BPD/001/2015). 


\section{REFERENCES}

Almeida D., Stefanoudis P.V., Fletcher D.H., Rangel C., da Silva E. 2014. Population traits of invasive bleak Alburnus alburnus between different habitats in Iberian fresh waters. Limnologica-Ecology and Management of Inland Waters 46: 70-76. DOI: 10.1016/j.limno.2013.12.003

Almodóvar A., Nicola G.G., Leal S., Torralva M., Elvira B. 2012. Natural hybridization with invasive bleak Alburnus alburnus threatens the survival of Iberian endemic calandino Squalius alburnoides complex and southern Iberian chub Squalius pyrenaicus. Biological Invasions 14 (11): 2237-2242. DOI: 10.1007/s10530012-0241-X

Alves M.J., Coelho M.M., Collares-Pereira M.J. 2001a. Evolution in action through hybridisation and polyploidy in an Iberian freshwater fish: A genetic review. Genetica 111 (1-3): 375-385. DOI: 10.1023/A:1013783029921

Alves M.J., Coelho H., Collares-Pereira M.J., Coelho M.M. 2001b. Mitochondrial DNA variation in the highly endangered cyprinid fish Anaecypris hispanica: Importance for conservation. Heredity 87 (4): $463-$ 473. DOI: 10.1046/j.1365-2540.2001.00929.x

Anonymous 2012. Climate change, impacts and vulnerability in Europe 2012-An indicator-based report, EEA Report No. 12/2012. European Environment Agency.

Arthington A.H., Dulvy N.K., Gladstone W., Winfield I.J. 2016. Fish conservation in freshwater and marine realms: Status, threats and management. Aquatic Conservation: Marine and Freshwater Ecosystems 26 (5): 838-857. DOI: 10.1002/aqc.2712

Bangs M.R., Oswald K.J., Greig T.W., Leitner J.K., Rankin D.M., Quattro J.J. 2018. Introgressive hybridization and species turnover in reservoirs: A case study involving endemic and invasive basses (Centrarchidae: Micropterus) in southeastern North America. Conservation Genetics 19 (1): 57-69. DOI: 10.1007/s10592-017-1018-7

Blachuta J., Witkowski A. 1983/1984. Natural hybrids Alburnus alburnus (L.) $\times$ Rutilus rutilus (L.), Alburnus alburnus (L.) $\times$ Blicca bjoerkna (L.) and Alburnus alburnus (L.) $\times$ Abramis brama (L.) from the Oder River. Acta Hydrobiologica 25/26 (2): 189-203.

Cabral M.J., Almeida J., Almeida P.R., Dellinger T.R., Ferrand de Almeida N., Oliveira M.E., Palmeirim J.M., Queiroz A.I., Rogado L., SantosReis M. 2005. Livro Vermelho dos Vertebrados de Portugal. [Red Book of Vertebrates of Portugal.] Instituto da Conservação da Natureza, Lisboa, Portugal. [In Portuguese.]

Carbonero Ciria J., Colino Rabanal V.J., Velasco Marcos J.C., Lizana Avia M. 2006. Biología reproductiva del Alburno (Alburnus alburnus) en el río Tormes. Ventaja competitiva de las múltiples puestas en la colonización de un nuevo hábitat y desplazamiento de especies autóctonas. Pp. 88. In: "EEI 2006" $2^{\circ}$ Congreso Nacional sobre Especies Exóticas Invasoras, 19-22 September 2006, León, Spain.
Cardoso A.C., Carrapato C., Martins A., Lousa H., Silva N., Pinheiro P., Almeida J., Reis F., Sousa D., Matono P., Rodrigues P., Oliveira J. 2015. Ação A3 Atualização da situação populacional do saramugo e das ameaças na bacia do Guadiana. [Action A3 - Update on the population situation of Spanish minnowcarp and threats in the Guadiana basin.] Relatório de progresso de 2015 da Ação A3 do Projeto LIFE 13 NAT/PT/000786 Saramugo. [In Portuguese.]

Clavero M., Hermoso V., Levin N., Kark S. 2010. Geographical linkages between threats and imperilment in freshwater fish in the Mediterranean Basin. Diversity and Distributions 16 (5): 744-754. DOI: $10.1111 /$ j.1472-4642.2010.00680.x

Crivelli A.J. 2006. Anaecypris hispanica. The IUCN Red List of Threatened Species 2006: e.T1199A3318827. DOI: 10.2305/IUCN.UK.2006. RLTS.T1199A3318827.en

Crivelli A.J., Dupont F. 1987. Biometrical and biological features of Alburnus alburnus $\times$ Rutilus rubilio natural hybrids from Lake Mikri Prespa, northern Greece. Journal of Fish Biology 31 (6): 721-733. DOI: 10.1111/j.1095-8649.1987.tb05275.x

Sousa-Santos C., Pereira A.M., Branco P., Costa G.J., Santos J.M., Ferreira M.T., Lima C.S., Doadrio I., Robalo J.I. 2018. Mito-nuclear sequencing is paramount to correctly identify sympatric hybridizing fishes. Acta Ichthyologica et Piscatoria 48 (2): 123141. DOI: $10.3750 / \mathrm{AIEP} / 2348$

Doadrio I. 2001. Atlas y Libro Rojo de los Peces Continentales de España. Dirección General de Conservación de la Naturaleza. Museo Nacional de Ciencias Naturales, Madrid, Spain.

Doadrio I., Perea S., Garzón-Heydt P., González J.L. 2011. Ictiofauna Continental Espanola. Bases para su seguimiento. Dirección General Medio Natural y Política Forestal, Ministerio de Medio Ambiente y Medio Rural y Marino, Madrid, Spain.

Epifanio J., Philipp D. 2000. Simulating the extinction of parental lineages from introgressive hybridization: The effects of fitness, proportions of parental taxa, and mate choice. Reviews in Fish Biology and Fisheries 10 (3): 339-354. DOI: 10.1023/A:1016673331459

Gozlan R.E. 2012. Mapping conservation priorities in the Mediterranean: The issue of non-native freshwater fish introductions. Fisheries Management and Ecology 19 (2): 89-92. DOI: 10.1111/j.1365-2400.2012.00853.x

Hernández Chávez C., Turgeon J. 2007. Asexual and sexual hybrids between Fundulus diaphanous and F. heteroclitus in the Canadian Atlantic region. Molecular Ecology 16 (7): 1467-1480. DOI: 10.1111/j.1365294X.2007.03239.x

Ilhéu M., Matono P., Bernardo J.M. 2014. Invasibility of Mediterranean-climate rivers by non-native fish: The importance of environmental drivers and human pressures. PLoS ONE 9 (11): e109694. DOI: 10.1371/ journal.pone.0109694

Ilhéu M.I., Matono P., da Silva J., Sousa-Santos C., Venade D., Emídio M., Jines C., Bernardo J.M., 
Costa A.M., Sousa D., Rodrigues P., Barão M.J., Cardoso A.C., Carrapato C., Lousa H., Silva N., Pinheiro P., Almeida J., Silva R., Alcazar R. 2016. Conservação do saramugo (Anaecypris hispanica) na bacia do Guadiana (Portugal). [Conservation of Spanish minnowcarp (Anaecypris hispanica) in the Guadiana basin (Portugal).] Relatório Final; Ação A4; "Estudo sobre o impacte de alburno (Alburnus alburnus) sobre as populações de saramugo." [Final Report; Action A4; "Study on the impact of bleak (Alburnus alburnus) on the populations of Spanish minnowcarp."] Projeto LIFE 13 NAT/PT/000786, Universidade de Évora, Évora, Portugal. [In Portuguese.]

Hermoso V., Clavero M. 2011. Threatening processes and conservation management of endemic freshwater fish in the Mediterranean Basin: A review. Marine and Freshwater Research 62 (3): 244-254. DOI: 10.1071/ MF09300

Hermoso V., Clavero M., Kennard M.J. 2012. Determinants of fine-scale homogenization and differentiation of native freshwater fish faunas in a Mediterranean Basin: Implications for conservation. Diversity and Distributions 18 (3): 236-247. DOI: 10.1111/j.1472-4642.2011.00828.x

Jenkins M. 2003. Prospects for biodiversity. Science 302 (3648): 1175-1177. DOI: 10.1126/science.1088666

Konishi M., Takata K. 2004. Impact of asymmetrical hybridization followed by sterile $\mathrm{F}_{1}$ hybrids on species replacement in Pseudorasbora. Conservation Genetics 5 (4): 463-474. DOI: 10.1023/B:CO GE.0000041027.64785.77

Lehner B., Döll P., Alcamo J., Henrichs T., Kaspar F. 2006. Estimating the impact of global change on flood and drought risks in Europe: A continental, integrated analysis. Climatic Change 75 (3): 273-299. DOI: 10.1007/s 10584-006-6338-4

Levy A., Doadrio I., Almada V.C. 2008. Historical biogeography of European leuciscins (Cyprinidae): Evaluating the Lago Mare dispersal hypothesis. Journal of Biogeography 36 (1): 55-65. DOI: 10.1111/j.13652699.2008.01969.x

Máiz-Tomé L., Darwall W., Numa C., Barros V., Smith K.G. 2017. Freshwater Key Biodiversity Areas in the north-western Mediterranean sub-region. Occasional Paper of the IUCN Species Survival Commission No. 64. IUCN, Gland, Switzerland, Cambridge, UK and Malaga, Spain. DOI: 10.2305/IUCN.CH.2017.SSCOP.64.en

Matono P., da Silva J., Ilhéu M. 2018. How does an invasive cyprinid can benefit from the hydrological disturbance of Mediterranean temporary streams? Diversity 10 (2): e47. DOI: 10.3390/d10020047

Morgado-Santos M., Carona S., Magalhães M.F., Vicente L., Collares-Pereira M.J. 2016. Reproductive dynamics shapes genomotype composition in an allopolyploid complex. Proceedings of the Royal Society of London Series B 283 (1831): e20153009. DOI: $10.1098 / \mathrm{rspb} .2015 .3009$
Muhlfeld C.C., Kovach R.P., Jones L.A., Al-Chokhachy R., Boyer M.C., Leary R.F., Lowe W.H., Luikart G., Allendorf F.W. 2014. Invasive hybridization in a threatened species is accelerated by climate change. Nature Climate Change 4: 620-624. DOI: 10.1038/ NCLIMATE2252

Perea S., Bohme M., Zupancic P., Freyhof J., Sanda R., Özuluğ M., Abdoli A., Doadrio I. 2010. Phylogenetic relationships and biogeographical patterns in circumMediterranean subfamily Leuciscinae (Teleostei, Cyprinidae) inferred from both mitochondrial and nuclear data. BMC Evolutionary Biology 10: e265. DOI: $10.1186 / 1471-2148-10-265$

Ribeiro F., Cowx I.G., Collares-Pereira M.J. 2000. Life history traits of the endangered Iberian Anaecypris hispanica and their implications for conservation. Archiv für Hydrobiologie 149 (4): 569-586. DOI: 10.1127/archiv-hydrobiol/149/2000/569

Ribeiro F., Leunda P. 2012. Non-native fish impacts on Mediterranean freshwater ecosystems: Current knowledge and research needs. Fisheries Management and Ecology 19 (2): 142-156. DOI: 10.1111/j.13652400.2011.00842.x

Rhymer J.M., Simberloff D. 1996. Extinction by hybridization and introgression. Annual Review of Ecology and Systematics 27: 83-109. DOI: 10.1146/ annurev.ecolsys.27.1.83

Robalo J.I., Sousa Santos C., Levy A., Almada V.C. 2006. Molecular insights on the taxonomic position of the paternal ancestor of the Squalius alburnoides hybridogenetic complex. Molecular Phylogenetics and Evolution 39 (1): 276-281. DOI: 10.1016/j. ympev.2005.08.009

Robson B.J., Chester E.T., Mitchell B.D., Matthews T.G. 2013. Disturbance and the role of refuges in Mediterranean climate streams. Hydrobiologia 719 (1): 77-91. DOI: 10.1007/s10750-012-1371-y

Rosenfield J.A., Nolasco S., Lindauer S., Sandoval C., Kodric-Brown A. 2004. The role of hybrid vigor in the replacement of Pecos pupfish by its hybrids with sheepshead minnow. Conservation Biology 18 (6): 1589-1598. DOI: 10.1111/j.1523-1739.2004.00356.x

Scribner K.T., Page K.S., Bartron M.L. 2001. Hybridization in freshwater fishes: A review of case studies and cytonuclear methods of biological inference. Reviews in Fish Biology and Fisheries 10 (3): 293-323. DOI: 10.1023/A:1016642723238

Sousa-Santos C., Collares-Pereira M.J., Almada V.C. 2007. Reading the history of a hybrid fish complex from its molecular record. Molecular Phylogenetics and Evolution 45 (3): 981-996. DOI: 10.1016/j. ympev.2007.05.011

Sousa-Santos C., Collares-Pereira M.J., Almada V.C. 2006a. Evidence of extensive mitochondrial introgression with nearly complete substitution of the typical Squalius pyrenaicus-like mtDNA of the Squalius alburnoides complex (Cyprinidae) in an independent Iberian drainage. Journal of Fish Biology 
68 (Suppl. B): 292-301. DOI: 10.1111/j.00221112.2006.01081.x

Sousa-Santos C., Collares-Pereira M.-J., Almada V.C. 2006b. May a hybridogenetic complex regenerate the nuclear genome of both sexes of a missing ancestor? First evidence on the occurrence of a nuclear non-hybrid Squalius alburnoides (Cyprinidae) female based on DNA sequencing. Journal of Natural History 40 (23-24): 1443-1448. DOI: $10.1080 / 00222930600934111$

Sousa-Santos C., Pereira A.M., Branco P., Costa G.J., Santos J.M., Ferreira M.T., Lima C.S., Doadrio I., Robalo J.I. 2018. Mito-nuclear sequencing is paramount to correctly identify sympatric hybridizing fishes. Acta Ichthyologica et Piscatoria 48 (2): 123-141. DOI: 10.3750/AIEP/2348

Sousa-Santos C., Robalo J., Almada V. 2014. Spawning behaviour of a threatened Iberian cyprinid and its implications for conservation. Acta Ethologica 17 (2): 99-106. DOI: 10.1007/s10211-014-0185-5

Sousa-Santos C., Robalo J.I., Collares-Pereira M.-J., Almada V.C. 2005. Heterozygous indels as useful tools in the reconstruction of DNA sequences and in the assessment of ploidy level and genomic constitution of hybrid organisms. DNA Sequence 16 (6): 462-467. DOI: 10.1080/10425170500356065

Sousa-Santos C., Robalo J.I., Francisco S.M., Carrapato C., Cardoso A.C., Doadrio I. 2014. Metapopulations in temporary streamsThe role of drought-flood cycles in promoting high genetic diversity in a critically endangered freshwater fish and its consequences for the future. Molecular Phylogenetics and Evolution 80: 281-296. DOI: 10.1016/j.ympev.2014.08.007

Sousa-Santos C., Robalo J.I., Pereira A.M., Branco P., Santos J.M., Ferreira M.T., Sousa M., Doadrio I. 2016. Broad-scale sampling of primary freshwater fish populations reveals the role of intrinsic traits, inter-basin connectivity, drainage area and latitude on shaping contemporary patterns of genetic diversity. PeerJ 4: e1694. DOI: 10.7717/peerj.1694

Swofford D.L. 1998. PAUP - phylogenetic analysis using parsimony (and other methods) version 4.0. Sinauer Associates, Sunderland, MA, USA.

Vinyoles D., Robalo J.I., de Sostoa A., Almodôvar A., Elvira B., Nicola G.G., Fernández-Delgado C., Santos C.S., Doadrio I., Sardà-Palomera F., Almada V.C. 2007. Spread of the alien bleak Alburnus alburnus (L., 1758) in the Iberian Península. Graellsia 63 (1): 101-110.

Wheeler A. 1978. Hybrids of bleak, Alburnus alburnus, and chub, Leuciscus cephalus in English rivers. Journal of Fish Biology 13 (4): 467-473. DOI: 10.1111/j.10958649.1978.tb03456.x

Witkowski A., Błachuta I. 1980. Natural hybrids Alburnus alburnus $\times$ Leuciscus cephalus and Rutilus rutilus $\times$ Abramis brama from the rivers San and Biebrza. Acta Hydrobiologica 22 (4): 473-487.

Witkowski A., Kotusz J., Wawer K., Stefaniak J., Popiołek M., Błachuta I. 2015. A natural hybrid of Leuciscus leuciscus (L.) and Alburnus alburnus (L.) (Osteichthyes: Cyprinidae) from the Bystrzyca River (Poland). Annales Zoologici 65 (2): 285-293. DOI: 10 .3161/00034541ANZ2015.65.2.010

Xenopoulos M.A., Lodge D.M., Alcamo J., Märker M., Schulze K., Van Vuuren D.P. 2005. Scenarios of freshwater fish extinctions from climate change and water withdrawal. Global Change Biology 11 (10): 1557-1564. DOI: 10.1111/j.1365-2486.2005.001008.x

Zardoya R., Doadrio I. 1999. Molecular evidence on the evolutionary and biogeographical patterns of European cyprinids. Journal of Molecular Evolution 49 (2): 227-237. DOI: 10.1007/PL00006545

Received: 31 January 2018

Accepted: 15 May 2018

Published electronically: 30 June 2018 